\section{NYTT OM LEGEMIDLER}

\section{Godkjenningsfritak - forskriftendring krever medisinsk begrunnelse for alle søknader}

Apoteket skal nå sjekke om legen har begrunnet hvorfor pasienten ikke kan bruke et legemiddel som er godkjent i Norge. Apoteket skal bare sjekke at det er gitt en grunn, ikke vurdere om begrunnelsen er god.

For å hindre at pasienten går tomhendt hjem fra apoteket, må legen oppgi den medisinske begrunnelse i selve søknaden om godkjenningsfritak.

\section{Et eksempel:}

Du velger å tilby en pasient vanlig melatonin for å behandle en døgnrytmelidelse. En relevant medisinsk begrunnelse kan da være:

«Det er behov for en annen formulering enn godkjent depottablett».

\section{Bakgrunnen for forskriftsendringen:}

Hensikten med endringen er å gjøre det tydelig for legen at bruk av ikke godkjente legemidler innebærer et personlig ansvar og at slik forskrivning skal være medisinsk begrunnet.

\section{Har du spørsmål om godkjenningsfritak?}

Send e-post til spesielt-godkjenningsfritak@legemiddelverket.no eller ring

22897593 mellom kl. 10: 00 og 12: 00.

\section{Risiko for manglende effekt av leuprorelin (Eligard)}

Leuprorelin er et legemiddel (syntetisk GnRH agonist) mot hormonfølsom prostatakreft $\mathrm{i}$ avansert stadium og settes med sprøyte. Fremgangsmåten for å blande væsken og pulveret i sprøyten er komplisert. Det er meldt om manglende effekt fordi dette ikke er gjort på riktig måte.

Det er avgjørende for behandlingen at blandingsprosedyren følges nøye. Feil kan få svært alvorlige konsekvenser for pasienten.

\section{Råd til leger:}

- Følg instruksjonen i preparatomtalen og pakningsvedlegget.

- Klargjør blandingen når produktet holder romtemperatur.

- Mål testosteronnivåene ved mistanke om feil administrering.

- Meld mistanke om bivirkning som følge av feil administrering til RELIS: relis.no/meldeskjema

Produsenten arbeider med å forenkle tilberedning og administrering av legemidlet.

\section{Julenøtt om legemiddelgjennomgang i NYL nr. 23/24 2014:}

NYL-redaksjonen gratulerer Mari Brox som vinner av vårt gavekort. Mari er fastlege og sykehjemslege i Sømna kommune.

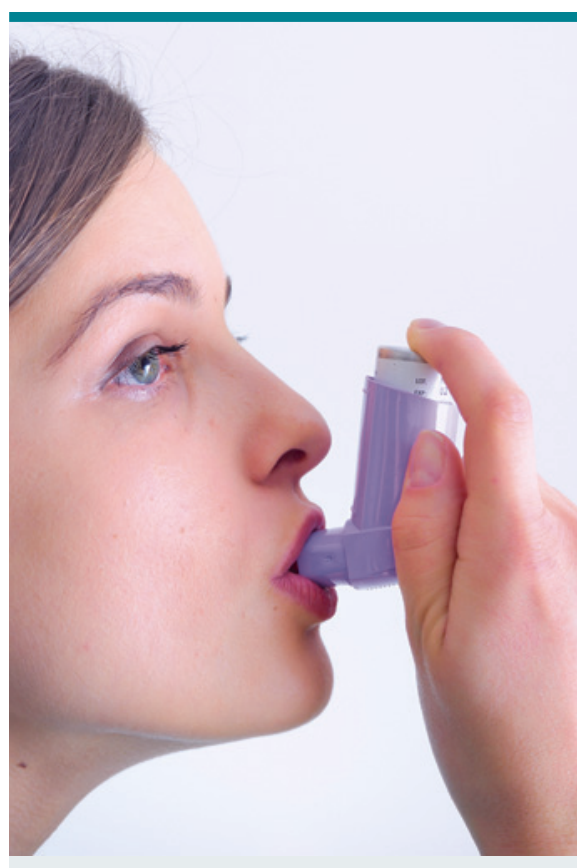

Olodaterol (Striverdi) på blå resept

Olodaterol inhalasjonsspray brukes som vedlikeholdsbehandling ved kronisk obstruktiv lungesykdom (KOLS). Legemidlet er en LABA (langtidsvirkende beta-2 agonist) og virker bronkodilaterende og lindrer symptomer hos voksne pasienter med KOLS.

Refusjon gis til pasienter med moderat til alvorlig KOLS (FEV1 mindre enn $80 \%$ av forventet verdi).

- Diagnosen må være verifisert ved spirometri.

- Hvis spirometri ikke kan gjennomføres, må årsaken journalføres.

Anbefalt dosering er 5 mikrogram gitt som to sprayer fra Respimat inhalator én gang daglig.

\section{Utvidet refusjon for apixaban} (Eliquis)

Analyser viser at apixaban er kostnadseffektivt ved behandling av dyp venetrombose (DVT) og lungeemboli (LE), og forebygging av tilbakevendende DVT og LE hos voksne pasienter. Rivaroxaban (Xarelto) har også refusjon for disse indikasjonene.

Apixaban har fra før refusjon for tromboseprofylakse ved kirurgi og atrieflimmer og atrieflutter.

\title{
Statens legemiddelverk
}

